\title{
Incentive taxation and sustainable growth in the Third World
}

Citation for published version (APA):

Backhaus, J. G. (1998). Incentive taxation and sustainable growth in the Third World. METEOR, Maastricht University School of Business and Economics. METEOR Research Memorandum No. 020 https://doi.org/10.26481/umamet.1998020

Document status and date:

Published: 01/01/1998

DOI:

10.26481/umamet. 1998020

Document Version:

Publisher's PDF, also known as Version of record

\section{Please check the document version of this publication:}

- A submitted manuscript is the version of the article upon submission and before peer-review. There can be important differences between the submitted version and the official published version of record.

People interested in the research are advised to contact the author for the final version of the publication, or visit the DOI to the publisher's website.

- The final author version and the galley proof are versions of the publication after peer review.

- The final published version features the final layout of the paper including the volume, issue and page numbers.

Link to publication

\footnotetext{
General rights rights.

- You may freely distribute the URL identifying the publication in the public portal. please follow below link for the End User Agreement:

www.umlib.nl/taverne-license

Take down policy

If you believe that this document breaches copyright please contact us at:

repository@maastrichtuniversity.nl

providing details and we will investigate your claim.
}

Copyright and moral rights for the publications made accessible in the public portal are retained by the authors and/or other copyright owners and it is a condition of accessing publications that users recognise and abide by the legal requirements associated with these

- Users may download and print one copy of any publication from the public portal for the purpose of private study or research.

- You may not further distribute the material or use it for any profit-making activity or commercial gain

If the publication is distributed under the terms of Article $25 \mathrm{fa}$ of the Dutch Copyright Act, indicated by the "Taverne" license above, 
revised, 3 September 1998

\title{
Incentive Taxation and Sustainable Growth in the Third World
}

\author{
Professor Dr. J.G. Backhaus \\ Maastricht University \\ Economics Department \\ P.O. Box 616 \\ 6200 MD Maastricht \\ The Netherlands \\ tel: $+31-43-3883652 / 3636$ \\ fax: +31-43-3258440 \\ email: f.schijlen@algec.unimaas.nl
}

Paper prepared for presentation at Tehran University, 19 August 1998 and before Select Committees of the Consultative Assembly (Parliament) of the Islamic Republic of Iran on 25 August 1998 


\title{
Incentive Taxation and Sustainable Growth in the Third World
}

\begin{abstract}
The judicious use of natural resources is a crucial prerequisite for sustainable growth not only in developed countries, but even more so in the Third World. To a substantial degree, natural resource use is determined by the tax structure governing a country's economic activity. When a tax constitution can be designed which stimulates the judicious use of natural resources, an important step towards achieving sustainable growth has been made. Designing such a constitution is not a simple task, however. For third world countries, the task is further complicated by at least three factors. On the one hand, the tax system has to be exceedingly simple, since both number and quality of tax instruments available to third world governments tend to be limited. Secondly, the legal system tends to mirror the state of economic development. This limits not only the tax structure an economy can bear; it also limits a government's ability to regulate natural resource use by legal means. Thirdly, the more elaborate a legal system, the more diversity it affords its country for economic activity, including opportunities for the division of labour.

The essay has eight sections. It starts with the discussion of the use of the environment and the natural resource endowment from the point of view of public finance theory. This point of departure is central, as it serves to identify the net product (le produit net) of economic activity after full consideration of the use of natural resources in the process of production. From this point of view, the question of what constitutes spillover effects or externalities in a market economy can be seen in the broad public finance perspective developed in section two. Section three discusses some standard problems in designing a tax constitution for a third world country. Section four explores possibilities for creating a framework in which the sustainable use of the natural resource endowment can take place. Central to the sustainable use is the notion that the environment has to be put to different uses, which raises the issue of the reversal of use dealt with in section five. The possibilities of ensuring reversibility of the use of natural resources is discussed in section six and a specific procedure is developed which is designed to ensure that reversibility of use can be achieved with simple administrative means, i.e. means that are available to third world governing authorities. The essay ends with some concluding observations.
\end{abstract}

J.E.L.-code: H20, K32, O10, Q28, 38 


\section{Incentive Taxation and Sustainable Growth in the Third World}

\section{Introduction}

The judicious use of natural resources is a crucial prerequisite for sustainable growth not only in developed countries, but even more so in the Third World. To a substantial degree, natural resource use is determined by the tax structure governing a country's economic activity. When a tax constitution can be designed which stimulates the judicious use of natural resources, an important step towards achieving sustainable growth has been made. Designing such a constitution is not a simple task, however. For third world countries, the task is further complicated by at least three factors. On the one hand, the tax system has to be exceedingly simple, since both number and quality of tax instruments available to third world governments tend to be limited. Secondly, the legal system tends to mirror the state of economic development. This limits not only the tax structure an economy can bear; it also limits a government's ability to regulate natural resource use by legal means. Thirdly, the more elaborate a legal system, the more diversity it affords its country for economic activity, including opportunities for the division of labour.

In trying to develop a perspective for the design of a tax constitution which allows sustainable growth in a third world scenario, this essay tries to merge insights from three economic subdisciplines which tend to be taught separately: public finance, natural resource economics, and development economics. True to the general theme of this conference, the emphasis will be less on modern and primarily on classical authors.

The essay has eight sections in addition to this introduction. It starts with the discussion of the use of the environment and the natural resource endowment from the point of view of public finance theory. This point of departure is central, as it serves to identify the net product (le produit $\underline{\text { net) }}$ of economic activity after full consideration of the use of natural resources in the process of production. From this point of view, the question of what constitutes spillover effects or externalities in a market economy can be seen in the broad public finance perspective developed in section two. Section three discusses some standard problems in designing a tax constitution for a third world country. Section four explores possibilities for creating a framework in which the sustainable use of the natural resource endowment can take place. Central to the sustainable use is the notion that the environment has to be put to different uses, which raises the issue of the reversal of use dealt with in section five. The possibilities of ensuring reversibility of the use of natural resources is discussed in section six and a specific procedure is developed which is designed to ensure that reversibility of use can be achieved with simple administrative means, i.e. means that 
are available to third world governing authorities. The essay ends with some concluding observations.

\section{1}

\section{The Use of The Environment in Public Finance Theory: Establishing the Net Product}

One of the central issues on which classical public finance theory has focussed is the correct establishment of the net product of a national (or for that matter local) economy. The difference between gross and net social product is the expense necessary to maintain the source of a particular revenue. Adam Smith states it aptly in chapter II of book II of his Wealth of Nations: "The gross revenue of all the inhabitants of a great country comprehends the whole annual produce of their land and labor; the net revenue, what remains free to them after deducting the expense of maintaining - first, their fixed, and, secondly, their circulating capital; or what, without encroaching upon their capital, they can place in their stock reserved for immediate consumption, or spend upon their subsistence, conveniencies, and amusements. Their real wealth, too, is in proportion, not to their gross, but to their net revenue." The simple principle has many implications. One is that taxes can only be levied on (a part of ) the net product, if we do not want to risk the availability of the revenue source altogether. Another is, that to the extent natural resources are used in the process of production, their maintenance has to be ensured as well by deducting the expenses to this end from the gross revenue of a particular economy. If these expenses for the maintenance of the endowment with natural resources of a country (a state, a city etc.) are not allowed for, changes in the composition of the capital stock will be taken for net income. The result is that more is spent than earned and the country (state, city, etc.) becomes poorer over time.

Although the principle is straightforward in its simplicity, its implementation is not. When the use of the environment occurs in the form of spillovers, it goes by unaccounted for. When implications of contractual transactions are latent or unforeseeable, they remain likewise unaccounted for. And when liabilities for damages cannot be attributed, the damages remain where they happen to fall, causing changes in stocks when they should have caused changes in flows. The damages will take the form of windfall losses, unrelated to the economic actitivities and decisions which had caused them. This lack of accountability results in a welfare loss to society as a result of "normal" economic acitivity which may go largely unnoticed. The nature and extent of this welfare loss will be discussed in the next section. 


\section{What Constitutes Spillover or External Effects?}

In classical public finance theory, taxes have the single purpose of providing revenues for essential governmental expenditures. In modern public finance theory, however, in as much as it follows the Pigouvian tradition, taxes also serve as instruments to correct for market failures. The Pigouvian tradition in public finance represents a departure from classical public finance theory in more than one respect, however. In assigning a regulatory function to the instrument of taxation, Pigouvian taxes no longer conform to the canon of taxation. Secondly, the Pigouvian view implies certain assumptions about the role of governmental authorities in the economic process. The view constitutes a clear departure from the classical Scottish view of governmental restraint. It constitutes a departure from the classical continental view as well, which would have relied on government to correct for market failure either by means of governmental entrepreneurial activity or by using legal instruments. Thirdly, the focus on technical spillover effects, while correct in and by itself, de-emphasizes the question of why the legal order allows for some spillover effects to remain externalized, while others have to be compensated for and thereby will be internalized. This third aspect has important implications for the problem of designing a tax constitution for a third world development scenario.

The presence of externalities by necessity implies a less than judicious use of natural resources. Negative externalities signal an overuse of some input, typically a natural resource, relative to market valuation. In a third world context, when the range of available tax instruments is limited, the Pigouvian tax/subsidy approach to spillovers is less realistic than in developed economies. It is therefore sensible to focus on the more traditional approach to handling spillover activities: the design of a legal system able to cope with such external effects.

In principle, the market economy is supported by three primary legal institutions: private property, freedom of contract and liability. These three fundamental institutions tend to be hampered in their ineffectiveness when confronted with environmental spillovers or externalities such as 1) latent or unforeseeable consequences of contractual exchange or 2) cases of multiple causation in which liability by any one party cannot be established, if the damaging effect occurred only as several parties acted together without 3 ) necessarily being able to anticipate the results of this concurrence.

If this constellation is seen as typical for an intractable environmental spillover problem, one might be led to the conclusion that both the common law and on the European continent the civil law seem to be out of tune with some of the typical problems posed by the use of the environment. However, it would be premature to jump to the conclusion that regulative, administrative legal approaches under these circumstances deserve priority. Throughout the Middle Ages, the prudent and sustainable use of the environment was ensured by detailed regulation of the technologies that could be employed. Allthough it is this developed state of technology which creates new 
possibilities for sometimes serious environmental damage, regulating technology use can by itself cause at least equally serious environmental damage if it stifles the introduction of new technologies, some of which will burden the environment less than existing ones. Therefore, rather than emphasizing a shift of legal regimes such as leaving the domain of private law and moving into regulatory administrative law, or even a Pigouvian tax/subsidy regime requiring even further informational input, it is desirable to investigate the specific conditions under which a regime of private law can adequately handle the treble problem outlined above. When spillovers elude the demarcation of private property rights, when results of contractural transactions are latent or unforseeable and when causes of damage cannot be clearly attributed, we face the possibility that the problem may have become intractable because of its decomposition. This possibility will be further considered in the next paragraphs.

In principle, damages will be considered to be correctly assessed if they reflect the harm demonstrably suffered by an individual or a group of individuals. By necessity, the harm has been suffered in the past and may continue through the present into the future, while the damages are assessed retro-actively in order to restitute the victim(s). The rule of liability, although applied retro-actively, still has effects into the future, to the extent that it is expected to be enforced and therefore deters harmful activities. The prospective deterrence effect is the weaker; the weaker is the link between harmful activities and the assessment of damages for compensation. As we noted in the beginning, in the case of many environmental harms, this link is very weak indeed: it is weak when spillovers evade the rule of property, when the effects of contractual transactions are latent or cannot be foreseen, and when multiple causes make it impossible to establish strict liability. As we take a dynamic perspective, the link becomes even weaker. In principle, a victim trying to recover damages not only has to prove the extent and cause of the harm, but above all he must have standing. Standing will in general be restricted to members of a particular jurisdiction and to presently living victims, typically cutting off trans-jurisdictional and intergenerational effects. Finally, the harm in general has to be directly suffered. Secondary effects, although not less important for an individual's net welfare, will not be considered. When due to heavy pollution the fruits of the garden taste unappealing, this will generally not constitute sufficient harm for a damage that can be recovered, nor the likely loss in the property value. When asbestos has to be removed from public buildings, the net public (tax/benefit) burden will have increased, yet a compensation will not be available.

The view grounded in the classical public finance tradition explained above yields a completely different picture. From the point of view of a public economy, be this a local, a state or a national economy, the overriding concern with a sustainable use of the environment is the need to keep natural resources intact for the use of future generations and to compensate for any encroachment upon the endowment of natural resources. Explicitly, this principle cannot imply a need to keep the entire endowment with natural resources in a pristine state. On the contrary: the establishment 
and performance of such institutions as the Kuwait Investment Office illustrates the principle: the extraction and sale of a natural resource (oil) and the re-investment of the proceeds in a widely spread portfolio of earning assets. If prudently managed, the capital stock of a country, of which the natural resources are a part, thus can be increased in its net present value. A harm is done to the economy if this stock is encroached upon and the depletion of one part of it is not offset by the increase in another.

This broader perspective comprises essentially all the spillover effects discussed separately in the standard environmental economics literature, yet it takes a different approach to their measurement. Instead of trying to establish the technical effects of e.g. asbestos exposure on cancer in human males, the public finance approach emphasizes the overall financial impact of all conceivably damaging factors on the health state of the working population. Instead of following the chain of causes and effects through from their biological beginning to their financial result, the procedure is reversed. Starting from the revenue sources of a public economy, the principle is to keep these revenue sources intact for the long term. In the example of asbestos, the health state of the working population is the relevant point of departure, since it is part of the endowment with factors of production at the disposal of the public economy. The impact of the various factors on cancer, such as diets, tobacco use, exposure to infections, reproductive and sexual behavior or exposure to occupational hazards to name some of the most important factors determining the health state of the working population with respect to cancer - needs to be assessed and measures have to be designed to keep the revenue source intact. In this particular example, the asbestos problem will be addressed in the context of other occupational hazards, of which it is a part. Instead of linking individual asbestos cases with the producers of asbestos, the entire pool of asbestos cases as part of the entire pool of workers exposed to hazardous materials is linked with the producers of the hazardous materials. This approach does not always assign environmental issues highest priority; the particular order given here ${ }^{1}$ indicates that as far as cancer is concerned, reasons other than occupational hazards may have to be addressed with higher priority. The important lesson to be learned from this example is, however, not that environmental issues may not be important after all. The lesson is rather that the different sources of environmental damages have to be grouped together in terms of their combined impact on the revenue base of the particular economy in question, in order to allow for their full assessment. Only once they have been fully accounted for can policies be designed to prevent the depletion of the resource base of an economy.

This principle, again, begs the question of its implementation. Implementation in a third world context requires special attention to the specific conditions of developmental public finance. This

$1 \quad$ See Richard Doll and Richard Peto, The Causes of Cancer, Oxford: Oxford University Press, 1981, pp. 12-56. 
is the subject of the following section.

\section{3}

\section{Public Finance and Economic Development}

Classical public finance as a separate subdiscipline of economics has its roots in the challenge posed by the disastrous experience of the Thirty Years War in Central Europe. Faced with the urgent need of developing their devastated and depopulated countries, European statesmen on the continent turned to their closest advisers, the cameralists, to design state measures in order to stimulate economic growth. In response, a voluminous literature developed and formed the basis for classical continental public finance theory. ${ }^{2}$ Traditionally then, economic development has been a main focus of public finance theory. ${ }^{3}$ A main focus of developmental finance is by necessity on capital formation. Capital formation has to be understood broadly as including all measures of a productivity increasing nature. In order to accomplish this task, state authorities have to create a climate which is conducive to investment. This includes the material infrastructure, but is also includes the immaterial infrastructure, a predictable and reliable legal order, a clean and efficient civil service and the assured prospect that investments today will actually pay off in the future. While these positive incentives for capital formation provide a substantial agenda for government, disincentives for consumptions (as the reverse program) are more difficult to handle. On the one hand, the tax effort of a developing country has to be much smaller than that of a developed country, since a much larger portion of the disposable income is needed for human reproduction. Only luxury consumption is conceivably amenable to taxation, although the limits have to be drawn sharply here as well, since too heavy a tax burden would create a disincentive for investment. In purely administrative terms, taxation is difficult when taxable entities are small, the activities unstable and the bookkeeping absent. As a matter of principle, parsimony with respect to tax instruments is a prerequisite for prudent developmental finance.

One area of taxation which is fairly insignificant in developed countries stands out as feasible in developing economies: the taxation of natural resources. In this respect, however, care has to be taken. There is general agreement in the literature that with respect to land taxation, the instrument

2 For a fuller account see Jürgen Backhaus and Richard E. Wagner, "The Cameralist: A Public Choice Perspective". Public Choise, 53, 1987, pp. 3-20.

3 The following is a standard rendition of some of the most important problems in developmental finance. A typical treatment can be found in chapter 34 of Richard E. Musgrave and Peggy B. Musgrave, Public Finance in Theory and Practice. New York, McGraw-Hill, 1989 (5). 
has to be handled prudently. The Musgraves write: "Effective land taxation is difficult when food is home consumed, the agricultural sector is largely nonmonetised, and land surveys are inadequate in providing proper valuations (page 595)". In addition, land taxes, as every other form of taxation, in order to be effective, have to be levied in line with received customs and convictions prevalent in that particular society. On the whole, there seems to be a consensus in the literature that with respect to land taxation, potential rather than actual income from land should be subject to taxation ${ }^{4}$. Obviously and in line with the preceeding analysis, only the potential net product of land can be subject to taxation. Furthermore the term "land" should be regarded as a shorthand for all natural resources available for production.

On the basis of this short summary of principles of developmental finance on the background of received principles of classical public finance, we may now turn to the issue of creating a framework for the sustainable use of the environment.

\section{4}

\section{Creating a Framework for the Sustainable Use of the Environment}

In doing so, another short digression into the history of economic thought is necessary, since such a framework has originally been proposed by Henry George.

Henry George (1839-97) was a self-taught American economist and political writer whose name is commonly associated with the notion of a Single Tax on land. George had worked as a sailor, printer and newspaperman when he became fascinated with the rapid and uneven development of California and began to probe the economic causes determining the price of land. This investigation he undertook in order to solve "the great enigma of our times", which he held to be "the association of poverty with progress" (1979, p. 10). His insights he systematically developed in his Progress and Poverty, first published in 1879. The book began to receive wider

See also Musgrave \& Musgrave, p. 599.

$5 \quad$ Progress and Poverty was first published by D. Appleton \& Co. in New York in January, 1880. However, in his preface, George refers to the November 1890 edition already as the fourth. His account of the editorial history is as follows: "This work was written between August, 1877, and March, 1879, and the plates finished by September of that year. Since that time, new illustrations have been given of the correctness of the views herein indicated [...]. But there has been nothing in the criticisms they have received to induce the change or modification of these views - in fact, I have yet to see an objection not answered in advance in the book itself. And except that some verbal errors have been corrected and a preface added, this edition is the same as previous ones." (1979: p. xxx). 
attention in Britain in connection with the Irish question and later made George famous in his own country, too. He spent the last part of his life as a public speaker at home and abroad, and it was George himself who made the Single Tax proposal a political issue in his (unsuccessful) bids for the mayoralty of New York first in 1886 and again in 1897.

His place in the history of economic analysis is aptly sketched by Joseph Alois Schumpeter who writes:

\begin{abstract}
The points about him that are relevant for a history of analysis are these. He was a self-taught economist, but he was an economist. He acquired most of the knowledge and of the ability to handle an economic argument that he could have acquired by academic training as it then was. In that he differed to his advantage from most men who proffered panaceas. Barring his panacea (the Single Tax) and the phraseology connected with it, he was a very orthodox economist and extremely conservative as to methods. They were those of the English 'classics', A. Smith being his particular favourite. [...] Even the panacea - nationalization not of land but of the rent of land by a confiscatory tax - benefitted by his competence as an economist, for he was careful to frame his 'remedy' in such a manner as to cause the minimum injury to the efficiency of the private-enterprise economy. [...] The proposal itself [...] is not economically unsound, except in that it involves an unwarranted optimism concerning the yield of such a tax. In any case, it should not be put down as nonsense. If Ricardo's vision of economic development had been correct, it would even have been obvious wisdom $(1954$, p. 865).
\end{abstract}

Schumpeter was correct in characterizing George's economic methods as conventional. Yet Progress and Poverty is not mainly a work of economic analysis, but a decidedly unorthodox and non-conservative social reformer's treatise. The book was written in order to provide the answer to a practical question of economic policy: How can we design an institutional order in which economic progress goes hand in hand with a reduction of poverty? This sounds almost like a paraphrase of the problem posed in the title of this essay. Schumpeter, like many other critics of

A twenty-fifth anniversary edition with a preface by Henry George jr. was published in 1905. The son explains that the publisher had insisted on George bearing the cost of making the plates, which George did in the shop of a friend in San Francisco. There, "an 'Author's Proof Edition' of five hundred copies was struck off" (1979: p. xxiii). A centenary edition prefaced by his grandaughter, Agnes George de Mille, appeared in 1979 in New York, published by the Robert Schalkenbach Foundation. This 1979 edition contains the aforementioned prefaces as well as an extensive index and a glossary of terms.

In conclusion, the first edition was San Francisco 1879, the first published edition New York 1880, and the final authorized edition with any changes New York 1890 (4). 
George, probably was incorrect in casually dismissing George's assertion about the practical possibilities of George's tax constitution from the standpoint of revenue yield. George may very well have been justified in his optimistic estimate of the yield of his Single Tax. This tax is a far cry from the real estate taxes a superficial reader may associate with the term "tax on land". Rather, as I try to explain on the following pages, George presents us with a comprehensive package of an environmental tax reform which, politically, has teeth. The program is, in fact, a tax constitution so comprehensive and far-reaching that no attribute could be more misleading than the term "conservative".

As this author reads Progress and Poverty, George comes across as a scholar in the best tradition of political economy. His analysis is motivated by a clearly defined social policy problem. George analyzes a problem in order to solve it. He succeded in designing a solution - his "remedy" - which relies on an institutional reform, i.e. George understood the interdependence between economic processes and the institutional order in which they take place. Finally, George went about his analysis in what today would be described as an inter- disciplinary approach, i.e. the questions he would consider were forced upon him by the subject matter under consideration and not by some disciplinary boundaries as they might have developed over time. When, e.g. he looks at the effects of his "remedy", he takes them up in this order: effects on (1) production, (2) distribution, (3) individuals and classes, and (4) social organization and social life (1979, IX).

The shortest book in Progress and Poverty, and at the same time the most important, is book VI in which George spells out his program. The central chapter, entitled "The True Remedy" barely covers two printed pages, and the solution itself is stated in just one sentence: "We must make land common property" (1979, p. 328).

The explosive potential of his program is wrapped into this rather innocuous sentence. The true extent of the proposal can be discerned by looking at the implementation rule and his concept of land. The implementation rule is stated in equally concise terms: "It is not necessary to confiscate land, it is only necessary to confiscate rent" (1979, p. 405). Finally, there is an underlying principle also worth reporting: "What is necessary for the use of land is not its private ownership, but the security of improvements" (1979, p. 398). This quote also points to Henry George's differentiation between improved and unimproved natural resources and the idea of the unearned improvement. The unearned improvement today turns out to be a hindrance to improvements tomorrow, since the possibility of gaining unearned improvements diverts energies from the very process of improving upon natural resources. In contemporary language, one might say that George tried to prevent wasteful rent-seeking activities by insisting on the principle that the benefits from improvements should accrue to whoever made the improvements, whereas unclaimable externalities belong to the common domain. 
The purpose of the entire reform program, according to this principle, is to encourage the use of land by designing a structure of property rights which allows individuals to reap the benefits of their labor, viz. the 'improvements' without barring the use of common property resources by others. His definition of 'land', as spelled out in a chapter appropriately entitled "The Meaning of the Terms" (1979, p. I 2) is not confined to the surface of the earth. His is an analytical definition based on the concept of factors of production. There are in George's model two original factors of production, called 'labor' and 'land'. 'Capital' is a secondary or derived factor of production, comprising only things "which have resulted from the union of these two original factors of production" (1979, p. 39). Since 'labor' is defined in a more standard way as "all human exertion", including, by the way, 'human capital', because "human powers, whether natural or acquired can never be classed as capital" (1979, p. 39); this leaves land as the all encompassing category of those original means of production which are not labor. In short, 'land' stands for the endowment of natural resources.

Characteristically, George defines land both analytically and by giving a sequence of examples illustrating the basic, comprehensive concept:

"The term land necessarily includes, not merely the surface of the earth as distinguished from the water and the air, but the whole material universe outside of man himself, for it is only by having access to land, from which his very body is drawn, that man can come in contact with or use nature. The term land embraces, in short, all natural materials, forces, and opportunities, and, therefore, nothing that is freely supplied by nature can be properly classed as capital. A fertile field, a rich vein of ore, a falling stream which supplies power, may give to the possessor advantages equivalent to the possession of capital, but to class such things as capital would be to put an end to the distinction between land and capital, and, so far as they relate to each other, to make the two terms meaningless" (1979, p. 3839).

It is obvious that, commensurate with technical progress, the window of opportunities granted by nature is pushed ever more open, and in this way the Georgian term 'land' assumes an ever more encompassing meaning. Simultaneously, the tax base of the State entrusted with the power of the Single Tax on the rent of natural resources is also broadening in pace with technical progress. While George defines 'land' in exactly the same way as we define natural resources today, George differs from most present-day proponents of environmental tax reform by wishing to encourage the prudent use of natural resources, whereas the standard approach today is to design schemes seeking restriction of such use.

The twin objective to open access to the use of all opportunities provided by the natural environment while, at the same time, granting full security of all improvements made upon the 
resource as found in the state of nature requires a partitioning of property rights along this distinction. This partitioning ${ }^{6}$ must have struck many of George's contemporaries as unusual or artificial. But, as he tries to show in his long survey of "Property in Land Historically Considered" (1979, VII 4), the partitioning should not be considered that unusual after all. You don't saw a ship in half if it is owned by two men, is his common sense comment. ${ }^{7}$

The partitioning of property rights is effected through the instruments provided by the modern tax state. Owners retain their property titles, but these titles are re-interpreted as designating the accumulated improvements, while the entire land rent remains in the common property of the state. The tax state, in this way, becomes a partner in the development of the land (country), a residual claimant of all the external benefits not appropriated by the individual owners.

Since this point is very important for understanding the dynamics of the Georgian scheme, let us look at his own statement:

Every productive enterprise, besides its returns to those who undertake it, yields collateral advantages to others. If a man plant[s] a fruit tree, his gain is that he gathers the fruit in its time and season. But in addition to his gain, there is a gain to the whole community. Others than the owner are benefitted by the increased supply of fruit; the birds which it shelters by far and wide; the rain which it helps to attract falls not alone on his field; and, even to the eye which rests upon it from a distance, it brings a sense of beauty $(1979, \mathrm{p}$. 435).

Assigning the unappropriable positive externalities of production to the State implies that George's concept of common property in natural resources actually goes beyond the original state of nature. It likewise includes the accumulated externalities or, put in more accessible terms, the cultural heritage of a country, its vegetation, climate, architecture and landscape, etc.. And, by virtue of the tax scheme, this cultural heritage also forms the tax base which the state is expected to foster.

"Nature laughs at a miser" (1979, p. 436), Henry George tells us in characteristic prose, and he certainly laughs at too parsimonious a use of the natural endowment. Not only is the tax scheme designed to minimize disincentives (1979; IX 1); stronger still, it co-erces people into either making productive use of the resources they possess or else relinquish them: "If land were taxed to

$6 \quad$ For a modern statement see Eirik G. Furubotn, 1979.

$7 \quad$ A reader has pointed to the difficulty of measuring what part of the "unearned" increment is due to nature, what part due to society, and what part due to entrepreneurship or effort. Dr. Krabbe and I have dealt with this issue elsewhere and at length. (See Backhaus and Krabbe, 1990) . 
anything near its rental value, no one could afford to hold land that he was not using" (1979, p. 413).

This growth oriented fiscal constitution, however, has a clever check on public sector growth built into it. It is here where the seemingly ideological and often misunderstood insistence on the Single Tax assumes importance. This feature of the Georgian proposal has always bewildered so many commentators, including the public finance expert ${ }^{8}$ Schumpeter. The explanation lies in the systematic unity of George's proposal. George suggested a tax constitution wich defines incentives faced by the tax collecting authorities. George wanted to foster progress by using the power to tax in a very specific way, but he was also suspicious of government bureaucracies (1979, p. VIII 3). By designating a broad tax base but limiting the power to tax to just one tax, the up to $100 \%$ tax on the rent of natural resources, he hoped to find the proper balance. On the one hand, the Georgian tax constitution creates incentives for those in public office to support equitable economic development, which flushes ever increasing tax revenues into public coffers. The State can grow unimpeded by any pre-conceived restrictions, as long as this public sector growth is financed from the increasing rental value of natural resources. On the other hand, as soon as the value of these rents stagnates or even declines, the state has to curtail its own expenditures. By virtue of the Single Tax constitution ${ }^{9}$, the State is harnessed into prudent, long term natural resource use, just as the private sector is co-erced into attaining the production possibility frontier. Built into George's reform is a 'tax constitution for Leviathan', to use Buchanan's term, a public choice approach avant-la-lettre. In one respect, however, George's tax constitution is different from the typical Leviathan tax constitutions which we owe to the modern public choice school. The limits on the size of the state budget are not predetermined, but determined according to the tasks the state may face. For instance, as natural resource use creates negative externalities, to the same extent increases the claim of the state on financial resources to mitigate these effects. On the other

8 This attribute might surprise the American reader. Yet, before coming to the United States, Schumpeter had distinguished himself in public finance. Schumpeter not only served as the first Secretary of the Treasury in the Austrian Republic precisely because he was considered a public finance expert; in this capacity he drafted a stabilization plan which could not come to fruition for reasons unrelated to the budget. He also held the chairs in public finance at the universities of Graz and Bonn. He did not receive a chair at the University of Berlin to which he had aspired, because the faculty felt that they did not need another public finance expert (next to Popitz).

This modern language should not lead the reader to suspect that the single tax might be without problems. It is conceivable that the single tax might not be Pareto optimal, notably because of effects on the timing of development. But one should keep in mind that George was making a contribution to economic policy, and not to the theory of optimal taxation. Even in the case of suboptimality just mentioned, one has to keep in mind that these cases require resort to second best analysis, and that it is by no means inconceivable that the lest distorting tax regime in the world of second best remains the single tax. 
hand, if nature is left in a pristine state, the state's claim on financial resources is very limited indeed; but so are the state's tasks in such an economy.

Even more surprisingly, this growth-oriented tax constitution clearly deserves the label "environmental" due to its built-in dynamic structure. By an "environmental" or "ecological" tax scheme one understands a fiscal constitution which induces economic agents to make optimal use of the environmental resources, neither squandering nor oversparing them. This is precisely what the Georgian system is designed to accomplish. The clue to the conservational feature of the Georgian tax constitution, again, lies in the partitioning of property into (internalizable) improvements (private ownership) and the rent of the resource as such (public ownership). The size of this rent is a positive function of the state of economic development of the surrounding economy and a negative function of the exhaustion of the natural resource.

Obviously $^{10}$, the rent on resource use is paid exclusively for the use of the natural endowment and not for its abuse. Depletion of a natural resource requires an additional compensation owed to the community which, in the Georgian model, is represented by the Tax State. The State is thereby entitled to two streams of revenues, viz. the rent collected from the use of its natural resources and, more generally, the environment; and the compensations for the abuse of those resources. Clearly, George was not a strict conservationist in the sense of sparing nature from any form of depletion. He wanted the ore to be mined and not to be left in the ground (1979, p. 38). Yet, at the same time, he wanted the community to extract a fair compensation for this impairment. While the guarantee of improvements is the core of the State guarantee of private property rights, impairments of common property resources require a compensation. The State thereby can plan the inter-temporal use of the natural resource endowment in the interest of overall fiscal concerns. We can conclude that George is fully in line with the classical principle of conserving the value of the natural resource endowment spelled out above.

The operational coherence and conclusivity of the abuse correction mechanism, of course, needs to be spelled out in institutional detail. Much will depend on the particular tax administration a country has set up. Such an administration would have to be backed by a system of tax courts in such matters as when judgement is required as to when an action constitutes an abuse or not ${ }^{11}$.

10 The following paragrpahs are not literally grounded in Henry George's Progress and Poverty; they rather follow directly from his definition of land as including all natural resources and his definition of improvements. But he did not himself spell out these implications, nor did he spell out details of the requisite implementation rule.

11 For the United States, one can start thinking about such procedures by looking at the reclamation of land used for surface strip mining. See US Surface Mining Control and Reclamation Act of 1977, (P.L. 95-87). This law calls for bonding and specifies landscape 
Yet the principle is simple enough to be of use even in the third world case of minimal administrative facilities.

\section{5}

\section{Reversal of Use}

This inter-temporal dimension embedded into Henry George's tax constitution assumes additional importance when we consider the change or reversal of uses environmental resources may be put to. Keeping the door to change and, notably, changes in resource use wide open is vital for preventing the rise and persistence of monopolies, including the state monopolies characteristic of many third world countries. The Georgian scheme, of course, requires that every resource be put to its most productive use. Again, the dynamic adjustment process is carefully conceived. The most productive use determines the rent of the resource, irrespective of whether the owner operates at the production possibility frontier or not. The automatic adjustment of rents, as a consequence of technical progress, constantly pushes economic agents to make the most judicious use of environmental resources. This implies that the Georgian system actually encourages the reversal and change of production methods involving natural resources. Unlike the present system of private property in land (1979, ch. VII 5), the scheme does not favor the first user at all, since a more valuable use makes it too expensive to continue the first use. The opportunity costs of natural resource use, by virtue of the land rent tax, enter into the present user's cost function.

Reversal of use can be more vexing a problem if natural resources are irretrievably devoted to some production (or consumption) process. The safeguard provided by the Georgian system is not a perfect one, since George opposed the conservation of natural resources for their own sake. Yet, George provided for two checks. The irreversable use of an environmental resource is checked on the one hand by the compensation payment required for abuse. The amount of this payment, in turn, will increase with the introduction of competing, more valuable uses as a consequence of technical progress. The second check lies in the communal nature of environmental resources. Since the environment is in the common property i.e. State domain, a political decision can override private commercial concerns. The political decision will be informed, above all, by the revenue consequences for the Single Tax State, a State which George has placed in the position of guardian of the environment in order to ensure its own fiscal survival.

Having explored George's tax constitution, we can finally integrate his contribution into the solution to our question.

contours, vegetation, etc. For Germany, an actionable procedure has been described in Jürgen Backhaus, 1988. 


\section{6}

\section{Ensuring Reversal of Use for Sustainable Development}

Ensuring reversability of resource use is again above all a matter of constitutional design. A political institution has to be found which is closely associated with the particular natural resource in question. Very often, the political boundaries co-incide poorly with natural environments. The case of the pollution of the river Rhine, the North Sea or the Baltic Sea point to vivid examples. But the same case of the Rhine also points to viable legal solutions. Since 1919, shipping on the Rhine is an international affair. The Rhine flows through the Lake of Constance, which is a condominium or jointly held property of Austria, Switzerland, and the two German states of Bavaria and Baden-Württemberg. However, both the Rhine and the Lake of Constance still lack their own legal identity which would make it possible to make a prudent and sustainable use of the natural resource in question. As we move down from the international to national and local jurisdictions, the problem becomes less and less intricate. A particular city, e.g., has its clearly circumscribed original endowment of resources of which its inhabitants and its politicians tend to be quite aware. The country we are currently meeting in, Iran, underscores the extent to which pristine wilderness made accessible is part of the natural resource endowment, as is the architectural and cultural heritage as part of the natural resource endowment we are presently confronted with, which implies that the ancient architectural treasures have to be counted as belonging to the capital stock which to maintain is the purpose of the entire Georgian proposal.

The first step in constitutional design then is to identify the correct political jurisdiction to which a particular natural or cultural resource belongs. ${ }^{12}$ This is done by making an inventory of the natural resources and their use in a particular country, state or city, and in cases of dispute assign the rights of use accordingly to the different public bodies in question. The licence to operate a business next to a National Park obviously carries a different rental value from one to operate in a more prosaic environment. Once the inventory has been arrived at and the uses established, the third step is to estimate the benefit levels associated with the uses acruing to the public authority in question. In the original Georgian proposal, these benefits are handled in terms of tax revenues exclusively. In terms of post-Keynesian public finance, this would be an unrealistic approach. Even local governments, and much more so state and federal or national governments have more than revenue seeking objectives. In the simplest of cases, we can postulate that governments will be interested in revenues and jobs. Very often, one translates into the other, at least in the mind of the treasurer who knows how much is needed in subsidies in order to attract additional for the Socialist Commonwealth of Great Britain, London, 1920. 
employment. ${ }^{13}$ These objectives have to be combined into a particular index, which can be a given sum expressing e.g. units of employment equivalents in monetary terms. The intensity of environmental use is then correlated with the current performance of the user of the environmental resource in terms of this monetary equivalent. We can, e.g., determine how many employment equivalents a business next to a National Park or a romantic bridge over the river Moldau mentioned above generates. Each resource use next to this location has to be assessed such a monetary equivalent. This is the rent to be collected from the resource user. If a business with heavy resource use generates comparatively low revenues or comparatively little employment, there is a strong incentive for it to move to a less desirable location and give way to a more productive resource use in terms of the policy objectives expressed in the monetary equivalents.

This system creates dynamic pressure by itself; yet the tax instrument can be combined with the typical licensing instrument used in traditional environmental regulation by again assigning monetary equivalents to the exercise of a license granted. In order to avoid grandfathering of resource use which typically is at the source of environmental waste, the successful new applicant has to prove that his intended resource use will yield a higher number of monetary equivalents than the present resource use. If the new licence is to be granted, the current licence holder has to be given adequate notice that the licence will be revoked unless he can improve his own performance up to the standard of the new intended use. At this juncture, there is an important role for either a developmental agency or an insurance company to play.

The authorities of any country or city, but even more so the authorities of a third world country or city face enormous difficulties in assessing the reliability and trustworthiness of different applicants. A country or city revoking one licence in order to grant it to another user, for reasons of credibility and for reasons of sound fiscal budgeting has to be assured that the new licence will actually produce a higher yield than the old one. Therefore, one viable strategy might be to insist that a bid for relicencing can only be successful if the performance of the applicant has been insured

A recent example may illustate the point. According to the Wall Street Journal's Asra Q. Nomani, Minnesota Gov. Arne Carlson signed a bill that gives NWA Inc.'s Northwest Airlines \$740 million in financial assistance, including \$320 million of direct loans for the carrier's operations. In addition, Minnesota lawmakers voted an estimated \$40 million in tax incentives to entice Northwet to build two maintenance facilities in the state, expected to employ 2,000 new workers. \$320 million of direct loans (part of the $\$ 740$ million financial assistance package) will be used to accelerate options on new jets made by Airbus Industrie, a European consortium. (The Wall Street Journal Europe, Monday June 3, 1991, p. 4.) By implication, the state of Minnesota values an additional maintenance job at the facility at $\$ 20,000$ in direct tax incentives and an additional $\$ 370,000$ in financial assistance. The second figure also reflects the state's desire to prevent the loss of jobs in the state that might occur if Northwest Airlines had to follow the example of Eastern Airlines. Such assistance packages are by no means unique to the state of Minnesota. 
for the duration of the licence applied for by either a private insurance company or some publicly backed developmental agency. Preventing imprudent or uncareful use of environmental resources by way of this procedure becomes a prime objective of the insurance company or developmental agency involved in writing insurance for these applications.

The infinitely more complicated issue of use reversal, again, cannot be handled without introducing an insurance solution. A basic distinction has to be made between current uses of the environment and new applications for environmental resource use. Current uses have to be dealt with in terms of creating the pre-conditions necessary for the reversal of use over a period of time. New applications can be dealt with in stricter terms. After a period of transition from one regime to the other, both forms of resource use, traditional and new ones have to be treated on an equal basis in order to avoid undue grandfathering. Again, international developmental agencies or insurance companies can play an important role.

\section{7}

\section{Sketch of a Procedure}

New applications are relatively simpler than the continuation of old uses. Consider the apllication for establishing an airport. In terms of the scheme outlined above, the application will indicate the number of monetary job equivalents expected to be generated by the airport. A certain amount of land will have to be claimed, and if for converting it to the airport use it need be covered with concrete; original natural environments will thereby be destroyed. The application also states the expected costs of reconverting the airport to its original state, with the cost estimates being based on bids by qualified bidders to carry out the work. The bids have to be insured or guaranteed and are thereby rendered qualified. The insurer or guarantor thereby assumes responsibility for the accuracy of the bids. The application further includes notice of insurance of the proposed number of monetary job equivalents effective upon granting the licence. This insurance policy covers the revenue base for the jurisdiction in charge of issuing the licence. Should the airport venture fail to generate the expected benefit in either revenues or employment opportunities, reversal of use is ensured and can be carried out after the proper notice has been given.

As far as traditional uses are concerned, the difficulty is to establish to what state the used natural resources would have to be reverted. That state of nature has to be described in a proper zoning decision, whereupon granting of the licence can be effected in the same way as described beforehand, involving again two insurance contracts. The basic rationale of this procedure is not dissimilar to current American practice. The novel aspect consists in the heavy use of insurance or guaranteeing relationships in order to contain the risk of damaging the environment by making improper licencing decisions. The sustainable use of environmental resources is made difficult by 
the presence of risk and uncertainty about the consequences of decisions separately but simultaneously taken by different actors. Without amendment, the private law system based on private property, freedom of contract and individual liability cannot effectively deal with environmental spillovers, latent or unpredictable consequences of contractual exchange and high transactions costs in attributing causes to effects, in particular if multiple causes bring about effects only when individual actors take their decisions separately but simultaneously.

\section{8}

\section{Conclusion}

There is a widespread tendency to move to regulatory regimes in order to alleviate these problems. Yet regulatory regimes by themselves do not have a better track record in containing environmental waste. The present paper explores the extent to which environmental damages can be insured, thereby creating prospective incentives in addition to the retro-active incentives present in the regime of private property. A procedure is outlined which, derived from classical principles of public finance, combines taxing and licencing decisions with insured bids on the strength of which decisions can be taken by necessarily underinformed public authorities.

The solution is meant to respond to the special needs of developing countries. The solution requires only a simple administrative infrastructure, and it allows international developmental agencies and large multinational corporations to play a role in the implementation. Natural resoursec are emphasized as the single most taxable assets of developing countries, and a tax constitution built on simple principles of classical public finance is described. This constitution is a selfinforcing one in stimulating sustainable growth through incentive taxation. 


\section{References}

Backhaus, J. and Wagner, Richard E.: "The Cameralist: A Public Choice Perspective". Public Choice, 53, pp. 3-20.

Backhaus, J. 1988. "Justiziable Bedarfsprüfung im Genehmigungsverfahren: ein Lüneburger Vorschlag", in: Jörg Finsinger and Jürgen Simon (eds.) Recht und Risiko, VVF, Munich, 94-112.

Backhaus, J, and Krabbe, J. 1990. "Incentive Taxation and the Environment: Complex - Yet Feasible", in: Richard Noyes (ed.) Now the Synthesis; Capitalism, Socialism and the New Social Contract, Holmes \& Meyer, New York; Shepheard - Walwyn, London, 1991, pp. 174-214.

Doll, Richard, Peto, Richard 1981. The Causes of Cancer, Oxford: Oxford University Press.

Furubotn, E. 1979. "Codetermination and the Efficient Partitioning of Ownership Rights in the Firm", Journal of Theoretical and Institutional Economics 135, 2, 207-215.

George, H. 1979. Progress and Poverty: An Inquiry into the Causes of Industrial Depressions and of Increase of Want with Increase of Wealth ... The Remedy. Robert Schalkenbach, New York.

Musgrave, Richard E. and Musgrave, Peggy B. 1989 (5): Public Finance in Theory and Practice. New York, McGraw-Hill.

Aggie Paulus, The Feasibility of Ecological Taxation. Antwerpen: Maklu, 1995

Schumpeter, J. 1954. History of Economic Analysis. Oxford University Press, New York.

Smith, Adam: The Wealth of Nations (1776), London: Dent. 1970.

Webb, Sidney, Webb, Beatrice 1920. Constitution for the Socialist Commonwealth of Great Britain, London. 